\title{
The Health Care University Lecturer as an Educationalist, Medical Specialist and Researcher
}

\author{
Elena Zheleva
}

\begin{abstract}
The university lecturer in his role as a medical specialist and a leader of the teaching process is a mediator between the theoretical course of lectures and the practical training sessions. He defines the objectives and tasks of each session and adopts the most appropriate role during it - that of a medical professional and an educationalist.

The scientific medico-pedagogical research practices at university level attempts to offer a solution to the problems related to the education and training of Health Care specialists. A characteristic feature of these research practices is the generation of new ideas and the acquisition of knowledge about the research object. They function as a process of obtaining information about the medical, social and pedagogical processes and phenomena. This information is used for their description, analysis and prediction.
\end{abstract}

Key words: Health Care Lecturer, University, Pedagogue, Medical Specialist, Scientific Medico-Pedagogical Research. 


\section{Profesor zdravotní péče jako pedagog, zdravotní odborník a badatel}

\section{Resumé}

Profesor zdravotní péče na vysoké škole, jakožto zdravotní odborník a vedoucí subjekt výchovné vzdělávacího procesu, je mediátorem mezi přednáškovým kurzem a praktickým školením. Ten sám stanoví cíle a úkoly každé lekce. Musí během lekce pro sebe zvolit nejvhodnější úlohu jako zdravotní odborník a pedagog. Vědecký zdravotně pedagogický výzkum na vysoké škole je orientován na řešení problémů vzdělávání a výchovy odborníků v oblasti zdravotní péče. Základné charakteristikou tohoto procesu je generování nových nápadů a dosažení nových poznatků o zkoumaném objektu.

Klíčová slova: profesor zdravotné péče, vysoká škola, pedagog, zdravotní odborník, vědecký zdravotně pedagogický výzkum

\section{Theoretical underpinnings}

The accession of Bulgaria to the common European educational space and the new economic realities pose new demands to the Health Care lecturer at university level. The achievements in the area of medical sciences and practices call for an updating of the health and illness theories. The new challenges define the need for the training of medical specialists who are: able to think globally and comply with the specific conditions of the situation; ready to manage their own learning; able to take responsibility of their own destiny; live and work successfully with others. The tasks assigned to university lecturers are related to the updating of the educational content and to the introduction of modern technologies into the educational process [2, p. 31-35].

Through his effective medico-pedagogical activity the university lecturer develops the professional profile of the future medical specialist. This professional profile depends to a large extent to his personality, pedagogical activity, tact and competences, communication style and skills for managing the teaching and learning process. Playing a leading role in the process of interaction with students and acting in accordance with the conditions of the educational process the university lecturer has a number of important functions: to plan, organize, conduct, coordinate and control his activity and the activities of students; to provide opportunities for the acquisition and reinforcement of knowledge, competences and skills through the active involvement of students in the completion of cognitive and practical activities in real hospital environment; to supervise the acquisition of professional skills; to provide optimal conditions for increased participation and learner autonomy; to manage the formation and development of 
the moral profile of students through skillful organization of the different activities and relations in the teaching and learning process; to provoke students' creativity on the basis of his tact and pedagogical skills; to direct students' attention to each of the situations emerging in the educational process; to organize and stimulate the cognitive autonomy of students and improve their skills for self-control and self-evaluation as a necessary prerequisite for the effective professional development of the future medical professionals [5].

The education and training of the Health Care specialists at university level involves the use of the following medico-pedagogical research studies by the lecturer: fundamental research studies / which provide information about the objective laws and regularities underlying the medical, social, and pedagogical phenomena and processes and which explain the concepts and terminology used/; applied research studies /which have a specific practical aim that is further developed to the level of a technology on the basis of the results of fundamental research/; implementation studies /which are related to the implementation of scientific results in the educational process at university level/; empirical medico-pedagogical research studies /which trace the changes and development of the personality as a result of different pedagogical practices/; theoretical research studies /where results are obtained on the basis of a summary of ideas governed by certain laws, and where theoretical frameworks that describe, interpret and predict the current state and future development of phenomena and processes are designed / [3, p. 9].

The successful development of a complete medico-pedagogical research study involves preliminary preparation which is followed by a diagnosis and analysis of the obtained results and their implementation in the practice. There are five distinct stages of the process of medico- pedagogical research studies: Stage 1: Research study design /planning, preparation and organization of the research study/; Stage 2: Conducting the research study /preliminary, main and concluding experiments/; Stage 3: Presentation and analysis of the results; Stage 4: Design and development of a research thesis; Stage 5: Trialing and implementation [3, p. 15].

The design of the medico-pedagogical research study is related to the development of a research concept /"clarifying the methodological approach, the content and the theoretical underpinnings of the study"1/ and research organization /"arrangement of elements, tasks and activities along the research timeline which leads to the successful achievement of the set objective ..."/. The research concept has three main functions: explanation of the initial theoretical concepts and frameworks; development of a methodology and definition of the research methods; planning of the different activities [1, p. 102].

The concept of the empirical medico-pedagogical research studies carried at university level comprises of two interrelated parts - methodological /which encom-

All quotations in this paper are translated by the author unless otherwise stated. 
passes a specific problem, the object and subject of the study, its aims and tasks, the research questions and hypotheses, the main terminology used/ and methodical / which includes the design of a plan, the choice of research instruments, the selection of a study sample, the choice of methods, criteria and research indicators/ [1, p. 102]. Each medico-pedagogical research study attempts to solve the problems related to the educational process at university level. The problem in the field of Health Care is a question or a group of questions to which the study has to give an answer.

The choice of a research problem is done on the basis of preliminary research and analysis of the literature and the medico-pedagogical practices. The criteria underlying the choice are: novelty and present day relevance, scientific significance and value, applicability, availability of sources of information, availability of research instruments, resources, etc. The topic of the medico-pedagogical research study, which is defined on the basis of the chosen problem, reflects the conception and the idea of the study. It has to be clearly stated so that it does not lead to ambiguous interpretations. Apart from that the topic has to comply with the specific characteristics of the study subject and to encompass a narrow set of problems, while at the same time its development should be motivated by practical and theoretical needs [3, p. 19].

\section{Aims of the research}

The aim of the current paper is to outline and highlight the organizational pedagogical conditions and factors for the professional development of the Health Care lecturer as an educationalist, medical specialist and participant in the scientific medico-pedagogical research studies conducted at university.

\section{Hypotheses or research assumptions}

The present research study focuses on the process and conditions which cater for the development of the Health Care lecturer as an educationalist, medical specialist and participant in the scientific medico-pedagogical research studies conducted at university. The university is the major centre for carrying out scientific research studies in the field of Health Care.

The object of the study is the Health Care lecturer as an educationalist, medical specialist and participant in the scientific medico-pedagogical research studies conducted at the Faculty of Public Health and Healthcare at the University of Ruse. 


\section{Methods}

The research methods used include: a survey, targeted interview, observation and pedagogical experiment.

\section{Findings and discussion}

The analysis of the research findings showed that the university lecturer plays a key role in the training of the medical specialist because he is the person who: creates the conditions for the development of professional knowledge, skills and competences; facilitates the development of students' professional clinical thinking; helps in the development of habits for solving independently scientifically oriented practical tasks; trains students to be disciplined and to bear responsibility for their education and professional experience; develops learners' readiness for continuous self-control and self-assessment; develops and maintains the high professional and cognitive interest of the future medical specialists and reinforces their motivation.

All research participants claimed that a well-organized and well-conducted training session is linked to the easy understanding of the discussed problem which leads to the achievement of the aims and the completion of tasks as a result of the active participation of both the lecturer and the students.

The university lecturer plays a leading role in raising students' awareness about the aims, tasks and formative role of the educational process in the training of the future medical specialists.

The research carried showed that the university lecturer applies common principles and requirements, as well as a clearly defined system of knowledge, skills, actions, approaches and qualities valid for the educational process at university level. He has to possess the following competences: pedagogical and andragogical knowledge; knowledge about the characteristic features, principles, methods, forms and techniques underlying the educational process; ability to link theory to practice in the implementation of a specific pedagogical activity; educational and practical skills; qualities such as: ability to work with people and win their respect, supportiveness, determination, enthusiasm, imagination, ability to promote enthusiasm in others, willingness to work diligently, analytical skills, ability to integrate a variety of tasks and flexibility when managing different situations.

It was established that the university lecturer in his role as a medical professional and educationalist has not only main functions such as: formative, educational, instructive but also subsidiary functions such as: evaluative, motivating, stimulating, communicative, informative, corrective, regulative and controlling. 
The research study proved that the profession of the university lecturer has an educational purpose and is linked with the most complex object - the student and his development as a medical specialist. A characteristic feature of the future medical specialist is the dynamic nature of his development during the course of training. The university lecturer needs to be equipped with the relevant competences to be able to respond to the challenges which the present day educational process poses. These challenges affect the teaching profile, characteristic features, status, position, professional behaviour and activities of the university lecturer. He exerts his professional duties in the context of ongoing reforms in the Health Care sector and has to demonstrate a humane attitude towards the patient.

The medico-pedagogical research study found out that the university is a centre for medico-pedagogical research conducted by Health Care specialists. Each one of the future medical specialists, who is an author of medico-pedagogical research paper, publishes the results of his studies, developed theoretical frameworks and findings in relevant scientific journals and conference volumes. His works are influenced and guided by the findings of all researchers in the field. Every researcher has a quick and convenient access to the scientific medical literature published globally.

It was established that the research topic developed by young researchers at universities can be chosen or defined by the research supervisor, while with more experienced young researchers it can be a follow-up of the ideas developed in previous research studies. It is advisable that the research topic is up-to-date and socially significant. Moreover, it should add additional insights to the Health Care theory and practice.

It was discovered that the methodology of the scientific Health Care medico-pedagogical research includes: a clear sequence of stages, timeline and available resources for its completion. It is necessary to have a draft plan for its development. The groups which will be used in the study /experimental and control groups/ are formed on the basis of the chosen strategy. This is followed by a decision on the ways to be used for the collection of samples and on the variables that will be measured. Then the criteria and study indicators are specified.

The next step is the design of a plan for the experiments or the observations. This is followed by the choice of the appropriate research instruments, i.e. all the necessary materials that will be used in the study. Then the methods for the analysis of the data gathered are chosen. A timetable schedule for the completion of the different tasks is designed. The timetable should correspond to the budget plan. Depending on the budget and the timing of each task a detailed work schedule is developed.

The study showed that the effect of intervention in the sector of Health Care could be traced with the help of experimental and control groups. Contrary to the control group the experimental group undergoes a specific procedure. The groups can be randomly selected or they can be formed on the basis of a specific criterion. When performing screening on diagnostic research in the field of Health Care, it is necessary to 
apply a criterion referenced standard, i.e. a well-established method which has certain accuracy and which can serve as a standard for comparison with the new screening or diagnostic method. In prognostic or cohort research studies a cohort /a group of people sharing common characteristics/is formed. This group is monitored for a period of time in a cohort analytical study in order to determine either the frequency of occurrence of an illness or the complications of a specific disease.

All study participants expressed the opinion that when conducting observational studies in the area of Health Care, the researcher makes a random choice of patients on the basis of "case - control of the case" or a forms a cohort of study subjects. The probable causes for an illness are studied when cases are examined. The patients who suffer from a specific disease /from the "case group"/ are compared with individuals who do not suffer from the same disease/the control group/in order to find out what the reason for the disease is. A series of cases are examined when describing the clinical characteristics of a specific disease. A control group is not used when a sequence of cases of patients treated in the same way is analyzed.

The research study proved the need for specifying the conditions for conducting experiments. It is also necessary to specify the region in which the research will be carried and the level of patient care there. The way in which the patients or study participants are selected, as well as the characteristics and symptoms that will be examined, are specified. The study sample can be random, consecutive /following the order in which the patients were examined by the doctor or the researcher/ or it can provide the best possible correspondence between the experimental or the control group.

The conducted medico-pedagogical research demonstrated that Health Care discussions end with a conclusion. It briefly presents the level of achievement of aims and tasks and the confirmation or rejection of the hypothesis, main contributions and unsolved issues which can be the focus of future research.

The analysis of the research findings confirmed that the publishing of the results of Health Care studies is necessary so that they are used by other interested professionals working in the same field.

\section{Conclusions}

The specific characteristics which form the profile of the Health Care university lecturer influence the development of the professional, personal and psychological profile of the future medical specialist as well as his way of thinking and behaviour. The university lecturer plays a key role in the enrichment of the knowledge of Health Care students and in the development of their competences, skills, habits and interests. The university lecturer uses his professional and personal competences, qualification, experience and 
achievements in order to find new regularities, to expand his teaching experience and activities and to transfer them to the future medical specialists.

He has a formative effect on students in his attempts to develop them as good professionals and people with specific intellectual, moral, esthetic and health culture. The medical specialist would not be able to develop without the help of the university lecturer. Moreover, it can be said that there is hardly a more valuable product than the educational work of the university lecturer and his effect on the development of the future medical specialist.

The motivation and active participation of the Health Care university lecturer in research activities carried in and outside the classroom is a prerequisite for the implementation of an educational process based on scientific medico-pedagogical research studies. Such an educational process improves the quality of education of the future medical specialists and their professional and personal development.

All this suggests that the Health Care university lecturer is an educationalist, medical specialist and participant in the scientific medico-pedagogical research activities conducted at the university.

\section{References}

1. Бижков Г., и колектив, "Дипломната работа не е лесна работа", София 2002г., [с. 467]

2. Воденичаров Ц., Митова М., Младенова С., "Медицинска педагогика", София 2008г., c. 31-35.

3. Ганчев, Г., и колектив, "Методика на педагогическите изследвания", Стара Загора, 2004, [c. 9].

4. Грънчарова Г., и колектив, "Методология на научните изследвания" Плевен 2004г., [c. 18-68].

5. Михайлов М., “Професията учител”, София 2006. 